Vol. 9(5), pp. 438-450, May 2015

DOI: 10.5897/AJ EST2014.1818

Artic le Number. C 7FE80C 52164

ISSN 1996-0786

Copyright (๑) 2015

Author(s) reta in the copyright of this artic le

African Journal of Environmental Science and

http://www.academic joumals.org/AJ EST

Technology

\title{
Accessibility and utilization of mobile phones for governance of water resources in the Lake Victoria Basin: Constraints and opportunities in Tanzania
}

\author{
H. J. Mongi ${ }^{1 *}$, A. N. Mvuma ${ }^{2}$, S. Kucel ${ }^{3}$, A. J. Tenge ${ }^{4}$ and M. Gabriel ${ }^{5}$ \\ ${ }^{1}$ Department of Information Systems, The University of Dodoma, P.O. Box 259, Dodoma, Tanzania. \\ ${ }^{2}$ Department of Telecommunications and Communications Networks, The University of Dodoma, P.O. Box 259, Dodoma, \\ Tanzania. \\ ${ }^{3}$ Department of Mechanical Engineering, Busitema University, P.O. Box 236, Tororo, Uganda. \\ ${ }^{4}$ Department of Development Studies, The University of Dodoma, P.O. Box 259, Dodoma, Tanzania. \\ ${ }^{5}$ Department of Content Development, The University of Dodoma, P.O. Box 259, Dodoma, Tanzania.
}

Received 31 October, 2014; Accepted 18 March, 2015

\begin{abstract}
Mobile phones are the world's fastest growing technologies in terms of coverage and adoption. This trend makes them a desirable information and communication technology (ICT) platform for addressing the striking challenges of water resources governance at all levels. Some of remarkable challenges in Lake Victoria Basin (LVB) that have negative impact on the water resources are rapid population growth, unfavorable climate change and variability, and non-sustainable urbanization. Mobile phones can contribute to addressing these challenges by addressing three key principles of governance: transparency in a manner that the resources are utilized by increasing population; accountability in both supply and demand sides of water resources for household, industry and agriculture; and participation of key stakeholders in policy formulation and decision making across temporal and spatial scales. This paper analyses the accessibility and utilization of mobile phones among various actors in the governance of water resources within LVB with the aim of identifying opportunities and constraints at community (micro), local government (meso) and national lake/river basin (macro) scale. To achieve this, three data collection sites were identified in Tanzania: Mwanza, Kagera and Mara. Data were gathered from key stakeholders through five methods: key informant interview, actors' panel discussion, observation, literature reviews and questionnaire administration. Qualitative data were subjected to contents analyses while empirical data were analyzed using Statistical Package for Social Sciences (SPSS). The analyses provided information on the constraints in access and utilization as well as opportunities availed by mobile phones. Furthermore, their potential for enhancing transparency, accountability and stakeholders' participation were summarized and discussed. Conclusion drawn from this study is that there is variation in access and utilization of mobile phones across scales of water resources governance in LVB that offer both opportunities and constraints. Integrated and innovative system that bridges the gap by capitalizing on the opportunities and minimizing the constraints could be an option.
\end{abstract}

Key words: Information and communications technology, mobile phones, Lake Victoria Basin, water resources, governance. 


\section{INTRODUCTION}

The ecosystem for information and communication technologies (ICTs) has been rapidly changing in the contemporary world. According to Selwhn (2002), it consists of a wide range of technological applications; digital broadcast technologies; telecommunications technologies as well as electronic information processing and resources. ICTs handle both information and telecommunicationincluding symbols, data, voice, images and video. Common ICT technologies are the internet, radio, television, mobile phones, fixed phones and all computers (mainframes, desktops, laptops, palmtops and tablets). A mobile phone is one of the mobile devices in the group of ICTs. Other devices include PDAs, wireless tablets and mobile computers (Jones and Marsden, 2006; Islam and Masum, 2010).

Mobile technology has been leading with new innovations. Mobile phone research and innovation have brought better brands, better portability and providing various functionalities depending on affordability, usability and interoperability (Ally, 2007; Jones and Marsden, 2006). Mobile phones can provide rigorous data gathering capability using voice-based technique, wireless internet gateway (WIG) or unstructured supplementary service data (USSD). Although when the first products were available in the market, the technology was afforded by wealth people, today it is an important item for every household if not every individual. Ordinary person in the rural area such as a farmer, a fishermen or a livestock keeper can afford owning one. Recent statistics indicate that of the world's seven billion people, six billion have mobile phones (UN News Centre, 2013). According to the International Telecommunication Union (ITU), the mobile phone adoption has far exceeded the total populations in many developing countries. Tanzania has recently recorded $59.2 \%$ mobile penetration rate (MDI, 2013). It is estimated that more than $80 \%$ of the world's population is covered by a mobile network, while in Africa alone; more than 600 million people have access to mobile phone services (InfoDev, 2013).

Mobile phones are changing the way people perform and interact across economic sectors. Writing in the context of agriculture sector, Loudon (2009) argue that mobile phones can provide data transfer functionalities enabling data sharing between and within the systems. Mobile phones can also be converged with other ICTs like radio and TV to respond to key issues like access to weather forecasts, cropping options as well as market information. Authors in the intersection between ICT and environment have shown that mobile technology can minimize the effect of environmental degradation. Ospina and Heeks (2010) contribute on the redundancy aspect of
ICTs; that is, the potential to increase the availability of resources. Redundancy concept has varying implications for computer and human beings. To the computer or mobile phone as a computing device, redundancy leads to inefficient utilization of resources, for example storing the same file in different folders. To human beings, redundancy is a good thing. In this context, Unhelkar (2009) simply define redundancy as "surplus capacity". For example, a mobile phone can enhance achievement of multiple objectives. These include improving access to financial capital which in turn may enhance access to infrastructures for efficient water use, improved systems for water distribution and also markets that are linked to water use efficiency (UNEP, 2010; Schuchardt et al., 2004). Mobile phones also can provide for rapid response through swift access and mobilization of financial assets (Duncombe and Boateng, 2009). Mobile phone services such as mBanking and m-Finance can improve the speed and efficiency with which local communities and general public at large can be mobilized to respond to water resource challenges. Geographic information systems' enabled mobile phones enhance communication, access to relevant location data, and mobilization of physical, economic and social resources that stakeholders may need to organize themselves while performing their roles in governing the water resources (World Bank, 2013; ITU, 2011).

Governance is often considered a central issue in water resources especially in the developing countries. According to Mbilinyi et al. (2007), governance is a system of administering and exercising power in democratic, transparency, strategic and ethical principles. Under this system, the entire society or concerned group of people are involved in planning, implementing and decision making processes. Rogers and Hall (2003) argue that governance is intensely a political term that refers to effective implementation of socially acceptable allocation and regulation. According to Wong (2009), participation is a core principle of good governance. To achieve sustainability especially within water resources, such participation should be made to happen through meetings, discussions and face-to-face communication at different levels (Mbilinyi et al., 2007). It is through these ways that potential value of the resource to the community and the environment is informed (Medalye and Hubbart, 2008).

Water resources challenges are location specific, although six categories of issues are often mentioned: inadequate water quality (Tebbutt, 1998), competing users, increasing demand amidst declining supply (WRG2030, 2009), climate change, (USDA, 2010; Sehlke, 2008; Frantz, nd), land-use change (Sehlke, 2008) and institutional

\footnotetext{
*Corresponding author. E-mail: hjmongi@yahoo.com.
}

Author(s) agree that this article remain permanently open access under the terms of the Creative Commons Attribution License 4.0 International License 


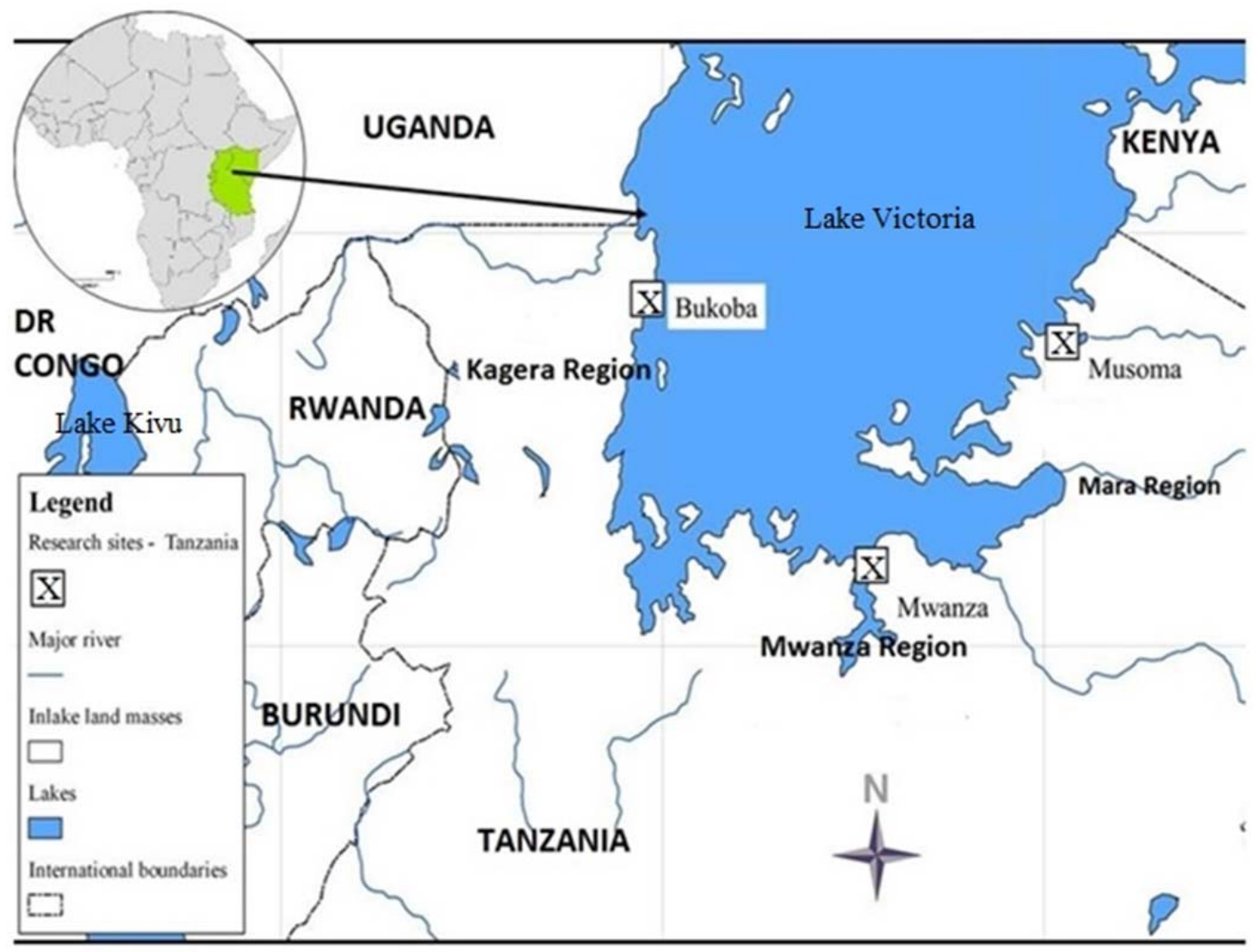

Figure 1. The map sketch of LVB showing the study areas.

barriers (Rogers and Hall, 2003; Weston, 2008; Weggoro and Ntumubano, 2010). Governance challenges affecting water resources have continually being addressed by fragmented policies, laws and regulations, weak enforcement of laws, weak institutional coordination and low community participation in decision making across spatial and temporal scales (Weggoro and Ntamubano, 2010, Okurut, 2010). Indicators of these challenges include: budgetary and financial mismanagement, irresponsible public expenditure, lack of transparency, lack of accountability and corruption. Impacts have been degradation of water sources, pollution, declining water quality and quantity and water use conflicts. Integrated approaches will enhance good governance and at the same time promote sustainability of water resources. Mobile phones provide tools that increase awareness, participation, accountability, coordination and communication at local, regional and international levels (Moum, 2006; Fudik et al, nd). These tools can simplify complex management decisions on natural resource management within a trans-boundary ecosystem. Despite the importance of mobile phones, there is inadequate knowledge on their accessibility and utilizations on a sector basis, on ruralurban basis and on various scales of actors in governance of water resources. Furthermore, mobile phones are used alongside other technologies whereby understanding their access and utilization constraints and opportunities would reduce technology duplication and avoid unnecessary wastage of important resources. This paper analyses the accessibility and utilization of mobile phones among various actors in the governance of water resources within Lake Victoria Basin (LVB) with the aim of identifying opportunities and constraints at community (micro), local government (meso) and national lake/river basin (macro) scale. Mobile technology also provides tools that increase awareness, participation, accountability, coordination and communication between stakeholders. These tools can simplify complex management decisions on natural resource management within a trans-boundary ecosystem like LVB. Mobile phones can further be used to predict and timely give early warning for the climate variability and changes.

\section{METHODOLOGY}

\section{Brief description of the study area}

LVB is a shared ecosystem among five member states of East Africa Community (EAC): Tanzania, Kenya, Uganda, Rwanda and Burundi. These five countries occur between latitudes $5^{\circ} 30^{\prime \prime} \mathrm{N}$ and $12^{\circ} \mathrm{S}$ and longitudes $41^{\circ} 50 " \mathrm{E}$ and $28^{\circ} 45^{\prime \prime} \mathrm{E}$ (Figure 1 ). The basin is blessed with resources such as water, forests, rivers and land for agricultural production, human habitats, wildlife, minerals and 
Table 1. Stakeholders at various scales that were consulted

\begin{tabular}{|c|c|c|c|}
\hline \multirow{2}{*}{ Scale } & \multicolumn{3}{|c|}{ Region } \\
\hline & Mwanza & Kagera & Mara \\
\hline Micro & $\begin{array}{l}\text { Irrigation schemes, Environmental } \\
\text { Management and Economic Development } \\
\text { (EMEDO), Organisational - Community } \\
\text { Livelihood Strategies and Support } \\
\text { (COLIS), Beach Management Unit (BMU) }\end{array}$ & $\begin{array}{l}\text { Irrigation schemes, Enviro-comet (ECOT), } \\
\text { Misenyi Area Development Project (ADP), } \\
\text { Kasambya Gugu Maji, Beach Management } \\
\text { Unit (BMU) }\end{array}$ & $\begin{array}{l}\text { Irrigation schemes, } \\
\text { Beach Management Unit } \\
\text { (BMU) }\end{array}$ \\
\hline Meso & $\begin{array}{l}\text { Magu District Water Development, District } \\
\text { Councils: Ukerewe, Mwanza, Misungwi; } \\
\text { Urban Water Supply Authority }\end{array}$ & $\begin{array}{l}\text { Bukoba Municipal Council, Misenyi, } \\
\text { Agricultural Office }\end{array}$ & $\begin{array}{l}\text { Musoma Municipal, SCC- } \\
\text { VI-Agroforestry Project }\end{array}$ \\
\hline Macro & $\begin{array}{l}\text { Office of Regional Administrative Secretary } \\
\text { (RAS), National } \quad \text { Environmental } \\
\text { Management Council (NEMC) }\end{array}$ & $\begin{array}{l}\text { Police Force, Tanzania Telecommunications } \\
\text { Company Limited (TTCL), Prevention and } \\
\text { Combat of Corruption Bureau (PCCB), } \\
\text { Misenyi AIDS and Poverty Eradication } \\
\text { Crusade (MAPEC), (Association Of Early } \\
\text { Childhood Care (AECC), RAS }\end{array}$ & $\begin{array}{l}\text { TTCL, RAS, Lake } \\
\text { Victoria Basin sub-office }\end{array}$ \\
\hline
\end{tabular}

Source: Field data.

fishery. The study was undertaken in three regions in the Tanzanian part of LVB: Mwanza, Kagera and Mara. Within these regions, three districts/municipal/councils were selected: Nyamagana and Misungwi for Mwanza, Bukoba/Misenyi for Kagera and Musoma for Mara (Figure 1). Criteria for selecting the area were the extent of water resource governance challenges, the availability of key stakeholders and their readiness to participate.

\section{Methods for data collection and analysis}

Design of the study involved a series of stakeholders meetings and workshops that were held in each participating region in Tanzania (Mara, Mwanza and Kagera). Discussions during the meetings and workshops included identification of roles in water resource governance, giving information about access to mobile phones and how best they are utilized or could be utilized to improve water resource governance over LVB. The following were the key stakeholders that were involved in different scales:

1. Institutions for water resource beneficiaries (NGOs, CBOs, local communities e.g., water use groups).

2. Institutions for water management (e.g. water use associations, Beach Management Units (BMUs), Lake Basin Water Authority, Local Governments Authorities).

3. Legal and regulatory enforcing organs at national, basin and regional levels (eg. Police, National Environmental Management Council (NEMC)).

4. Policy making institutions (e.g. ministries in-charge of resources management).

5. Research institutions

Other methods of data collection were: key informant interview, observation, document reviews and questionnaire administration. Sample size for questionnaire administration was estimated using a proportion's formulas as follows:

$n=\frac{t^{2} \times p(1-p)}{e^{2}}$ where $n$ is the required sample size, $t$ is the confidence level at $95 \%$ (standard value of 1.96), $p$ is the estimated participants in water resource governance in the study area (30\%) and $e$ is the standard error that tolerated $5 \%$ (standard value of 0.05 ).

The raw data were coded and converted to electronic databases using SPSS software. The data bases were edited and checked for reliability and validity. Then data were analyzed using the SPSS and MS Excel computer programmes. Basic statistics including mean, frequency and percentages were computed and used to compare the proportion of responses in each category. Cross tabulation was used to compare the results within and between country sites. Mean values for data collected by Likert scale questions were computed to obtain the weighted mean (average) for each variable. This computation was done according to the procedures for computing the weighted means when you have different contributions from different groups (Bowerman et al., 2011; Devore and Peak, 1992) in accordance with the equation below:

$$
M_{w}=\frac{\sum w_{i} X_{i}}{\sum w_{i}}
$$

where $M_{w}$ is the weighted mean (average) for Likert scale data set on variable $i, W_{i}$ is the relative frequency of responses in percentage for variable $i$, and $X_{i}$ is the value of variable $i$ in Likert scale $(1,2,3,4)$. Opportunities and constraints of mobile phones were accessed based on the socio-economic characteristics of the respondents and industry market trends specific to Tanzania.

\section{RESULTS}

\section{Characteristics of respondents}

Respondents came from various backgrounds and organizations engaged either directly or indirectly in water resource governance as depicted in Table 1. Table 1 further categorizes their organizations with respect to their scales of governance of water resources, that is, 
Table 2. Personal characteristics of respondents in the study area.

\begin{tabular}{lccc}
\hline Characteristics & Description & Frequency & $\%$ \\
\hline \multirow{2}{*}{ Sex } & Male & 156 & 71 \\
& Female & 64 & 29 \\
& & & \\
& $<18$ & 2 & 0.9 \\
Age (years) & $18-35$ & 86 & 38.9 \\
& $36-50$ & 96 & 43.4 \\
& $>50$ & 37 & 16.7 \\
& & & \\
Highest education level & Informal & 10 & 4.7 \\
& Primary & 133 & 62.1 \\
& Secondary & 71 & 33.1 \\
& Tertiary & & \\
& & & \\
& $1-4$ & 31 & 16.8 \\
& $5-10$ & 37 & 20 \\
Length of stay (years) & $11-15$ & 22 & 10.8 \\
& $>15$ & 95 & 51.4 \\
\hline
\end{tabular}

Source: Field data

micro, meso and macro. The table indicates that there was adequate representation of relevant stakeholders in the LVB water governance. Table 2 describes the community respondents with respect to their sex, age, highest level of education and length of stay in a particular area. These variables are important in understanding the opportunities offered and constraints at a very individual point of view.

The results presented in Table 2 show that male were dominant participants. The results do not reflect the actual proportion of female in the population where it is known that the proportion of female is relatively larger. However, the results reflect the situation where majority of head of households are male and they are the ones who frequently appear in meetings and influence decision making. These groups (male and female) are likely to have different perception, knowledge and ability to utilize ICT facilities due to differences in access to resources and information. Normally, women in these countries have limited access due to traditional social barriers although the situation is improving with time. Results in Table 2 further show that about $82 \%$ of respondents are aged between 18 and 50 years. This is generally the most active group in water resources management where they participate in building associations; they are the water resource users in production in industries, agriculture, fisheries and at household level. Moreover, about half (51\%) of respondents in Tanzania have stayed in their current places of residence for more than 15 years. This suggests that they have accumulated adequate experience and knowledge on issues related to LVB water resources governance challenges.

\section{Respondents' perception on constraints to mobile phone access and utilization}

\section{Mobile phone access}

Access to mobile phones as measured by individual ownership of the device or accessibility through the household relationship showed that about $30.4 \%(\mathrm{~N}=289)$ of the respondents owned mobile phones as shown in Table 3. This is lower than the average teledensity/penetration of $64 \%$ reported by Tanzania Communications Regulatory Authority (TCRA) in June 2014. The discrepancy is attributed to the fact that teledensity reported by TCRA considers number of registered SIM cards without taking into account multiple ownerships while the study considered accessibility to mobile phones. It is not uncommon for users of mobile services to own multiple SIM cards without mobile phones ownership.

However, as compared to other ICT assets, mobile phones rank the highest followed closely by radios while access to computers and modems ranked the lowest. The findings thus suggest that integrating mobile phones with community radios could be the best option for empowering stakeholders at community level for participation in governance of LVB water resources. The same conclusion can be inferred from Figure 2 which shows ownership of ICT facilities by age of respondents.

Figure 2 further shows that the highest percentage of respondents in age groups 18 - 35 and 36 - 50 years own mobile phones (36 and $61 \%$, respectively) followed by radio (33 and 57\%, respectively). This implies that respondents in these age groups have more access to mobile 
Table 3. Community access to mobile phones against other ICT facilities by communities.

\begin{tabular}{|c|c|c|c|c|c|}
\hline \multirow{3}{*}{ Type of ICT Facilities } & \multirow[b]{3}{*}{ Sex } & \multicolumn{4}{|c|}{ Own ICT asset } \\
\hline & & \multicolumn{2}{|c|}{ Yes } & \multicolumn{2}{|l|}{ No } \\
\hline & & Frequency & $\%$ & Frequency & $\%$ \\
\hline \multirow{3}{*}{ Radio } & Male & 64.0 & 32.0 & 136.0 & 68.0 \\
\hline & Female & 22.0 & 24.7 & 67.0 & 75.3 \\
\hline & Total & 86.0 & 29.8 & 203 & 70.2 \\
\hline \multirow{3}{*}{ Mobile phones } & Male & 63 & 31.5 & 137 & 71.9 \\
\hline & Female & 25 & 68.1 & 64 & 71.9 \\
\hline & Total & 88 & 30.4 & 201 & 69.6 \\
\hline \multirow{3}{*}{ Television } & Male & 18 & 9 & 182 & 91 \\
\hline & Female & 9 & 10.1 & 80 & 89.9 \\
\hline & Total & 27 & 9.3 & 262 & 90.7 \\
\hline \multirow{3}{*}{ Computer } & Male & 11 & 5.5 & 183 & 92 \\
\hline & Female & 4 & 4.5 & 85 & 95.5 \\
\hline & Total & 15 & 5.2 & 268 & 93.1 \\
\hline \multirow{3}{*}{ Internet modem } & Male & 10 & 5 & 190 & 95 \\
\hline & Female & 5 & 5.6 & 84 & 94.4 \\
\hline & Total & 15 & 5.2 & 274 & 94.8 \\
\hline
\end{tabular}

Source: Field data.

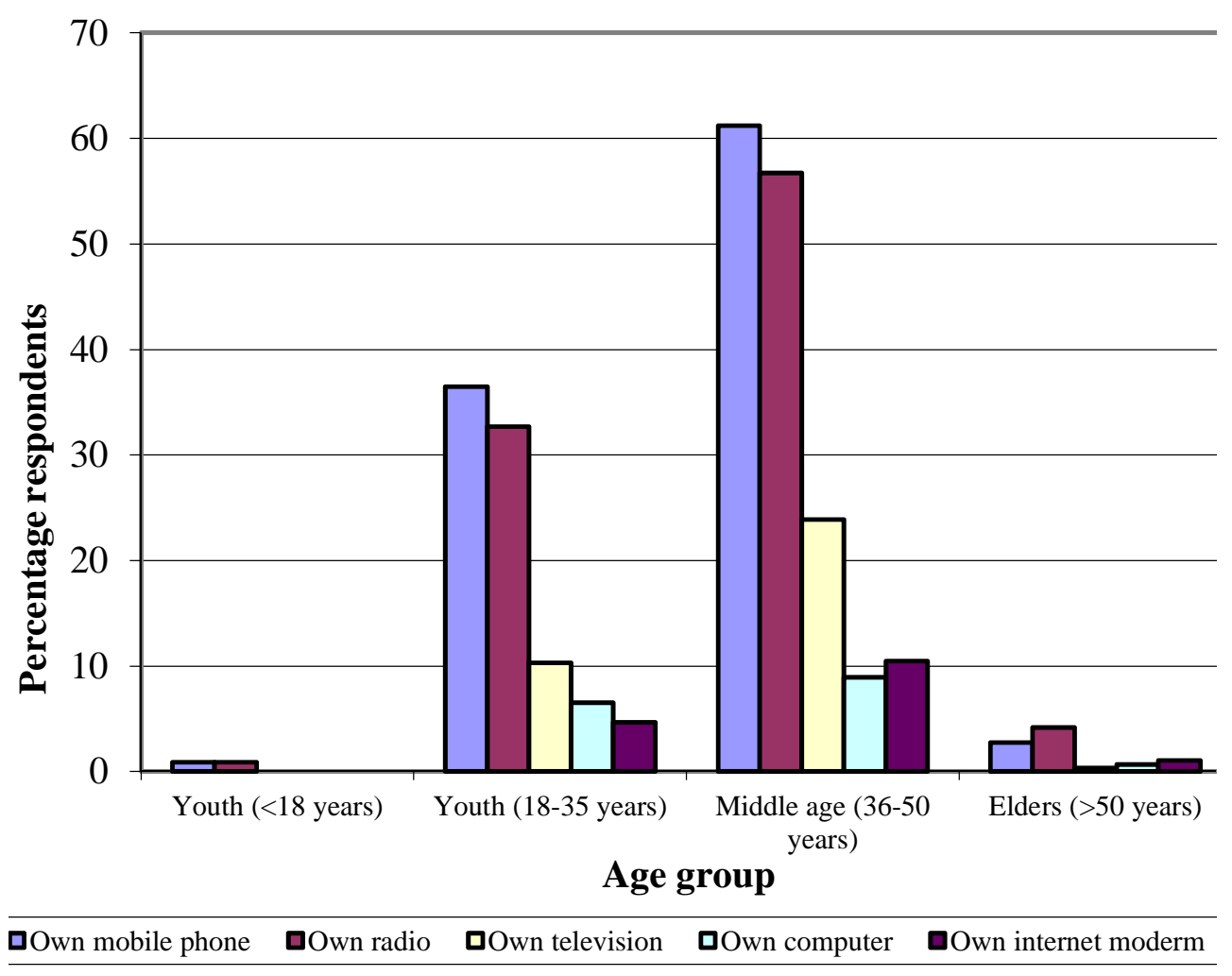

Figure 2. Ownership of ICT facilities by age of respondents of community's members (Source: Field data). 


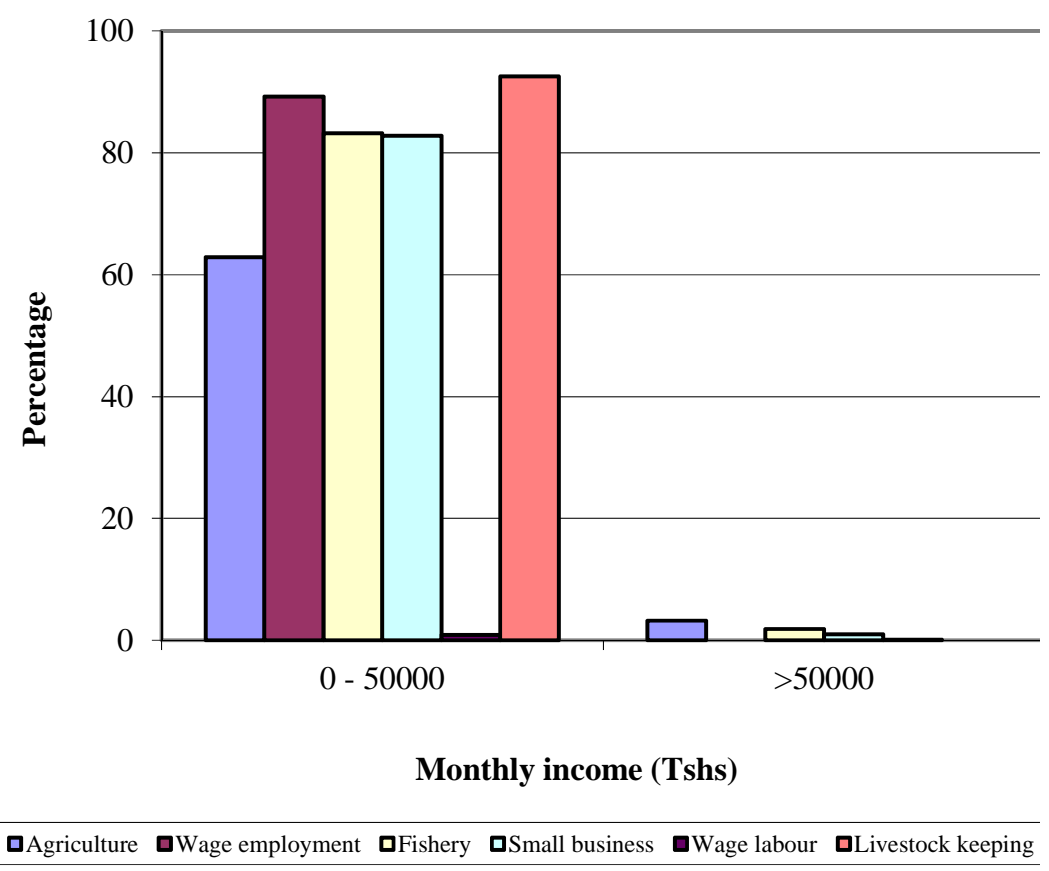

Figure 3. Monthly income levels of community members without mobile phones (Source: Field data).

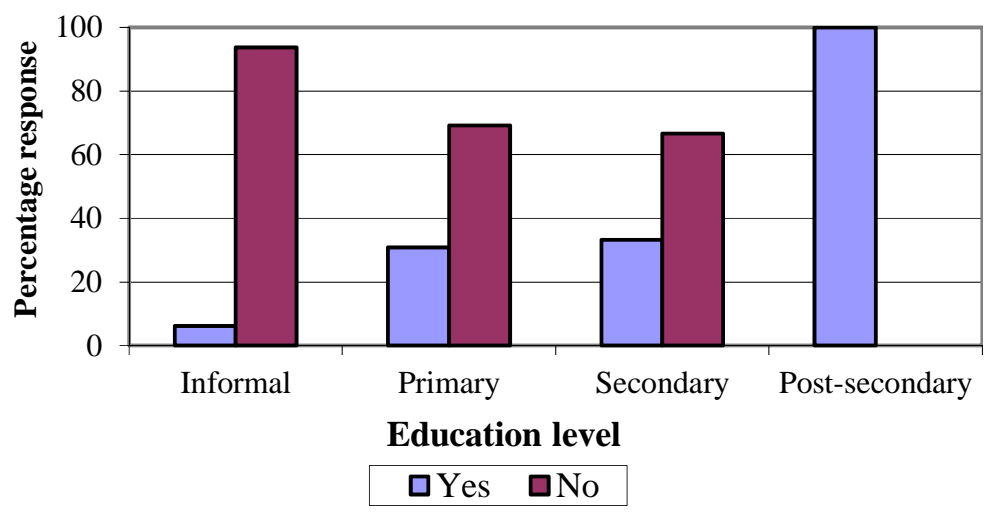

Figure 4. Community members with and without mobile phones by education level (Source: Field data).

phones than other ICT facilities.

Figure 3 summarizes the respondents who do not own mobile phones by their income categories across different economic activities. Results show that between 65 and $90 \%$ of those who do not own mobile phones $(69.8 \%$ of all respondents) were earning monthly income equal or less than Tshs $50,000 /=$ or close to US $\$ 32$. Although it is sometimes difficult to ascertain income of an individual, this reflects the major obstacle facing stakeholders at the lower scale of governance of water resources.

Figure 4 shows the distribution of respondents with and without mobile phones across different education levels. The results indicate a declining gap in ownership as someone advances into higher education. For example, while for respondents with informal education the gap was $87 \%$, for post-secondary education the gap dropped to $0 \%$. This trend can be an indication of a correlation between education level, likelihood of employment and income.

\section{Awareness on capability of mobile phone services}

The study indicated that there is generally low awareness about potential services that mobile phones can offer. However, the difference was more apparent in ruralbased community members (Kagera and Mara) as 


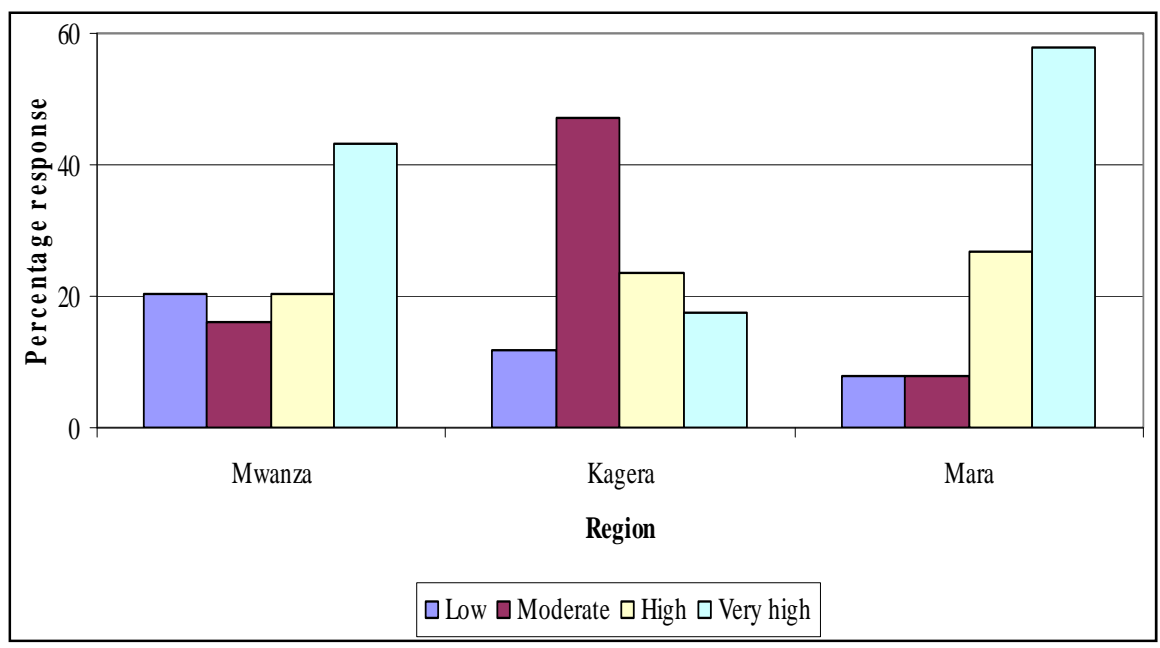

Figure 5. Awareness on the potential of mobile phones to provide reliability of information (Source: Field data).

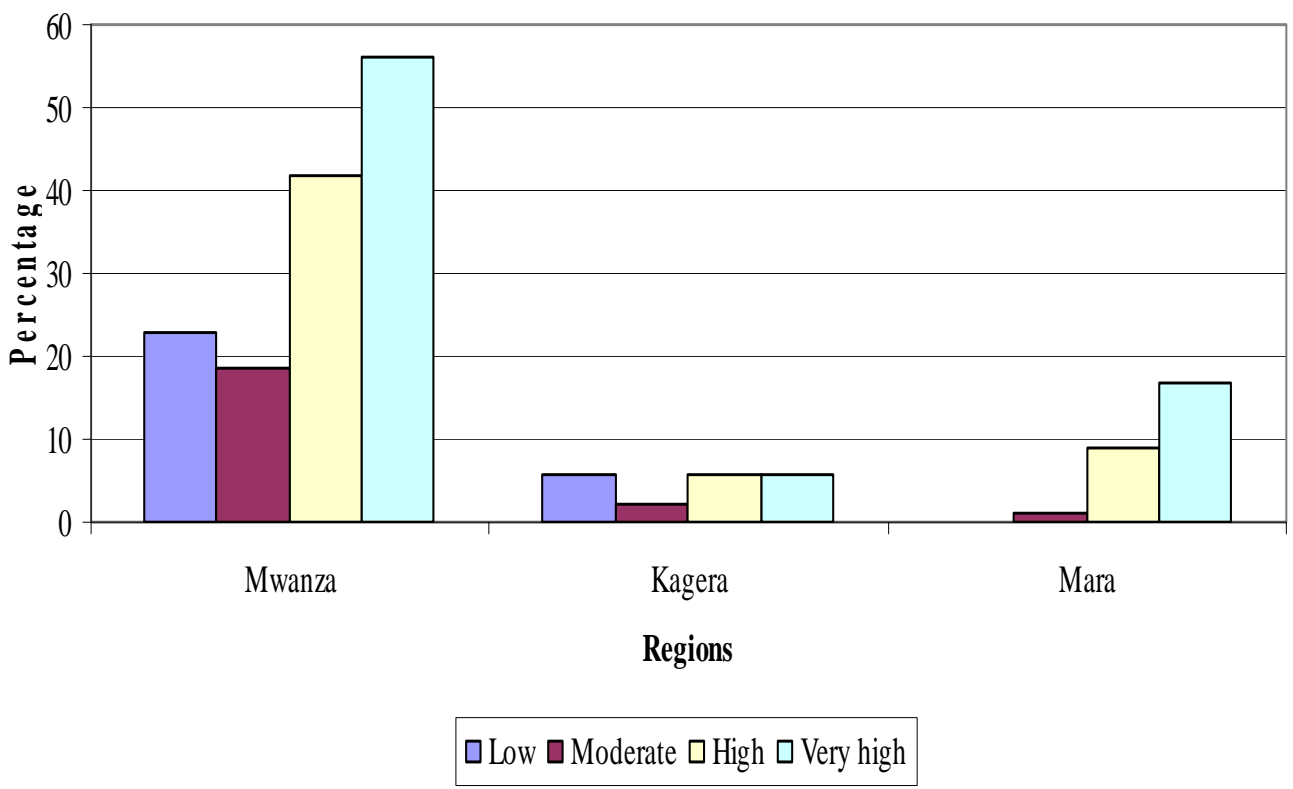

Figure 6. Awareness on the potential of mobile phones to provide for rapidity (Source: Field data).

compared to their counterparts in urban and peri-urban areas (Mwanza).

Figure 5 summarizes the respondents' perception on reliability of mobile phone services such as M-Payment. Most respondents seem to have high to very high trust on mobile phone money services but others especially those from rural areas (for example, Bukoba) have shown little hesitance.

Rapidity is an advantage that a mobile phone can provide in mobilizing resources and responding to urgent needs for water resource challenges. Respondents' perception on rapidity is shown in Figure 6. Majority of respondents were aware of the capacity of mobile phone to offer rapid service delivery.

\section{Perceived cost of mobile phone and network coverage}

There was general perception that the cost of acquiring and running the mobile phone is high. Majority of respondents attached the low access and usability to costs of 
acquiring and operating the mobile phone. Respondents had a varying perception on mobile network coverage (Figure $7 b$ ). Those in mostly urban and peri-urban areas reported good to very good network coverage. However, many rural dwellers in all the study areas reported moderate to poor coverage.

\section{DISCUSSION}

\section{Constraints and possible halting strategies}

There was generally acceptable level of awareness on the quality of service that a mobile phone can provide among respondents who owned the device. However, issues related to acquisition cost and coverage emerged among the same group. In addition, there was a huge group of respondents (69.6\%) who did not own a mobile device. In fact, this was relatively smaller when compared with those who did not own other ICT assets such as radio (70.2\%), television (90.7\%), computer and internet modem $(>93 \%)$ as detailed in Table 3 . To this, very large group awareness is crucial along with empowerment through enabling them to possess a handset. This can be achieved through concerted efforts by the government and other development partners by embracing supportive policies to underprivileged members of the community. Ownership by age is favorable as the best majority owners belonged to age groups between 18 and 50 years (Figure 2). These are groups actively engaged in water resource governance and share most of its challenges. Majority were small irrigation water users, fishermen and water users at household level.

Studies in Nigeria indicated that despite good penetration rate at the national level, many rural dwellers, approximately $71 \%$ had no cell phones, thus excluded from the benefits of the mobile phone revolutions (Hultman, 2013). The government facilitated development of mobile based system to curb corruption activities in agricultural input distributions, identify subsidies recipient's name, address and phone numbers; therefore keep proper records for monitoring and evaluation. The government envisages further benefit from the system including using the records for policy and decision making since government policy must be based on evidence and well analyzed data. In order to make the project more inclusive, the government of Nigeria planned to distribute over 10 million mobile phones to the neediest famers (ibid). This is an example of government driven initiative that would increase community empowerment in governing their water resources.

Experience has indicated that income poverty and low education have greater chances of isolating the vulnerable communities from access to public services and hence hinders participation in water resource governance activities. Results from this study indicated that there was a close relationship between access to mobile phones and levels of education and income. Over $90 \%$ of respondents interviewed through questionnaires $(\mathrm{N}=289)$ were at the micro scale. They had qualification of varying levels (Table 2). The higher the educations level, the more the chance of an individual to own a mobile phone. This was so for the income levels (Figures 3 and 4). The best explanations could be that as one goes up the education ladder, has a greater chance of earning a higher income and eventually own a mobile phone. Lower education and income levels could also reflect in the ways in which respondents perceived quality of service of mobile networks (Figures 5 and 6). It was to be expected that most respondents without mobile phone could not express their perceptions. While the industry figures show improvement in network coverage and total cost of ownership, respondents' perception indicated this was still a constraint especially in rural areas (Figures $7 a$ and $b$ ). This is also a matter of policy and regulation enforcement at lower levels of governance.

Vertical and horizontal approaches have to be considered in order to improve governance of water resources through mobilization of active participation, high levels of accountability and transparency. The structure of water resource governance may be considered as a triangle with a wide base. This bottom level or the low scale (micro) consists of many participants with a lot of transactional information among them. Addressing access and utilization constraints at this level is mandatory.

\section{The opportunities from mobile phones and how to harness them}

The mobile industry in Africa consists of a wide range of solutions which most of them can be adopted in governing water resources in Tanzania and beyond. Vodafone and Accenture identified 12 opportunities for mobile phone technology to increase income and productivity (Vodafone/Accenture, 2011). Some of these platforms are already widely used in Africa, while others are still in early stages of implementation. The list include mobile payment systems, micro-lending platforms, mobile information platforms, help lines, small logistics, traceability and tracking systems, mobile management of supplier networks, mobile management of distribution networks, trading networks, tendering platforms and bartering platforms. Although most of these examples have been drawn from agricultural sector, they can serve other sectors as well with or without slight modification.

To take full advantage of the opportunities availed by these systems, other pre-conditions have to be fulfilled. These include the availability of mobile network in the areas where water resources are threatened by governance challenges, affordable acquisition costs of handsets and their day to day use, supportive institutional arrangement that would enhance the users' ability to benefit from the technologies. 


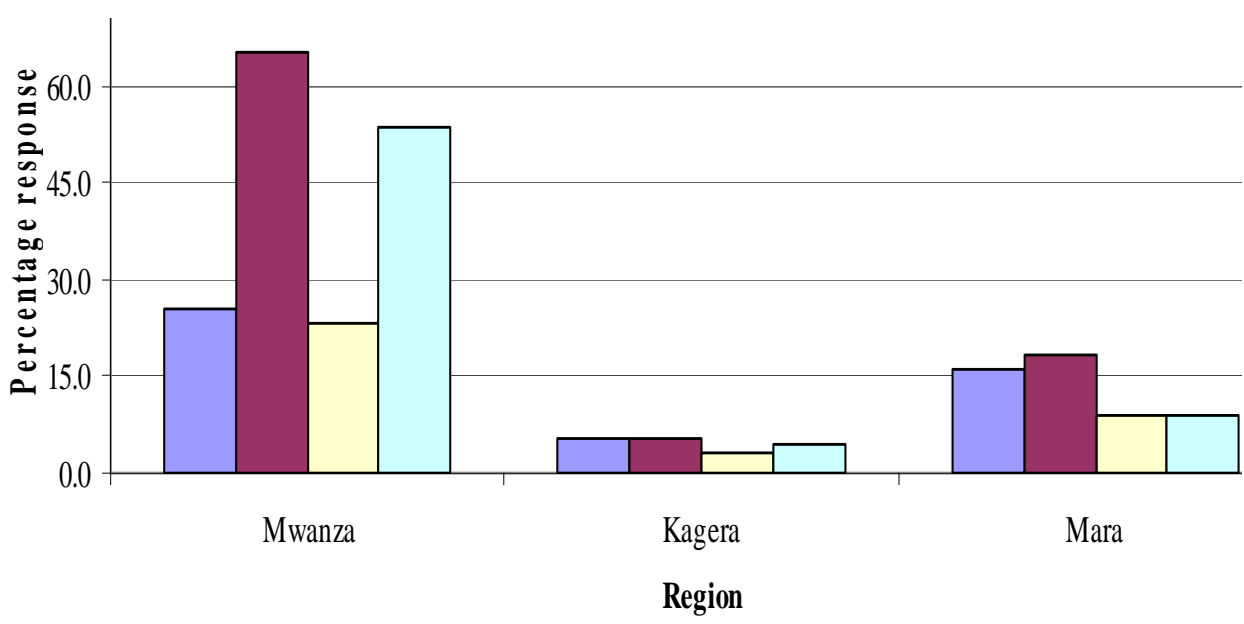

$\square$ High $\square$ Moderate $\square$ Low $\square$ Very low

Figure 7a. Perceived cost of ownership of a mobile phone (Source: Field data).

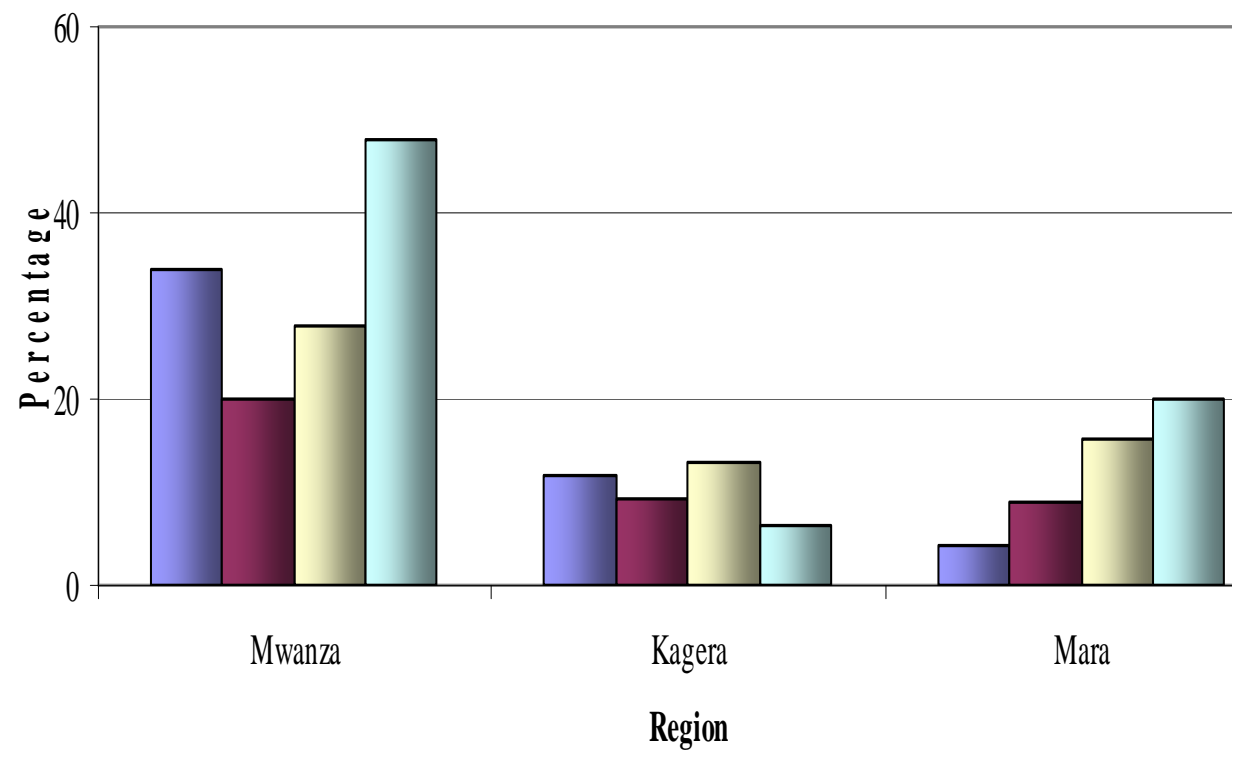

Figure 7b. Perceived mobile network coverage (Source: field data).

Results in Figure 8 shows that penetration rate has been increasing over the past seven years with a very good trend $\left(R^{2}>0.9\right)$. Penetration is measured as ratio of total mobile connections to the total population. Therefore, the results indicate that about $59 \%$ of population is already reached by the mobile connection. Further to this, Figure 9 shows that the users are responding to the increasing coverage. The number of subscribers to mobile phone services (voice, SMS and data) has been increasing in the same trend as the penetration.

Although fixed phone services have been there for long, their performance in terms of subscription has remained in the lower tail. Both penetration and subscription trends are opportunities to increase use of the mobile phones both in urban and rural areas.

There was slight variation between respondents' perception on total cost of ownership (TCO) of mobile phones and the industry position. While most respondents perceived the costs to range from high to moderate (Figure 7a), the industry data has shown that TCO had been declining sharply $\left(\mathrm{R}^{2}>0.89\right)$ over the last four years (Figure 10). It is therefore a matter of policy to 
Afr. J. Environ. Sci. Technol.

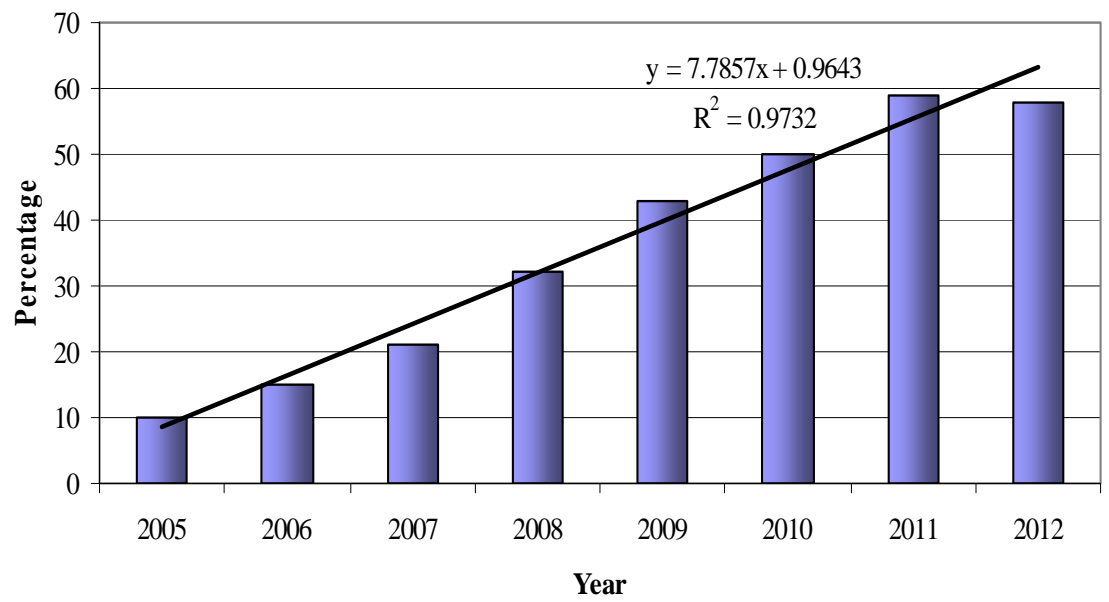

Figure 8. Mobile network market penetration (Source: TCRA (2012)).

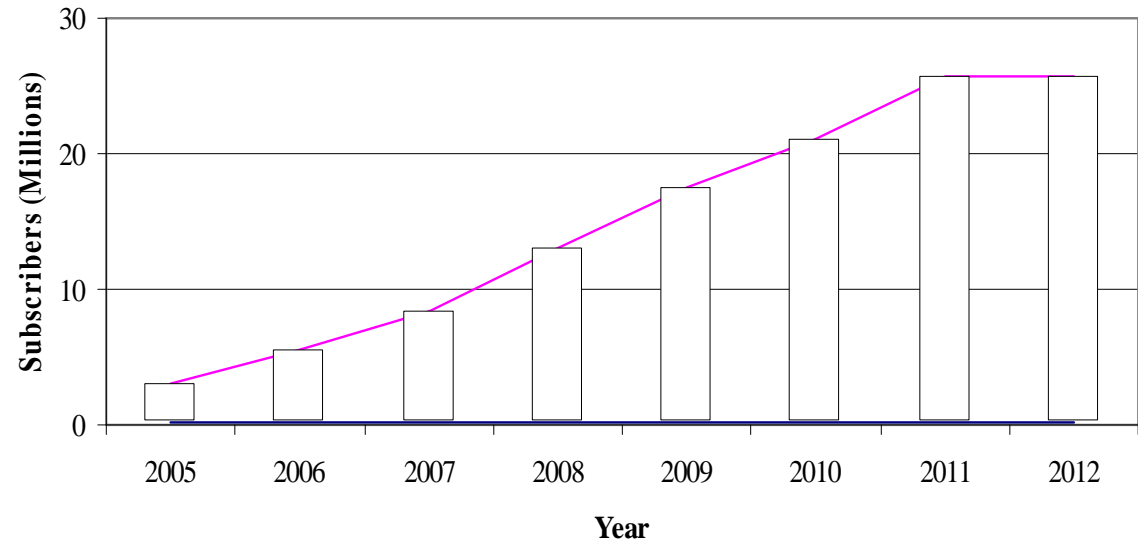

— Fixed — Mobile

Figure 9. Subscription trends for mobile networks (Source: TCRA (2012)).

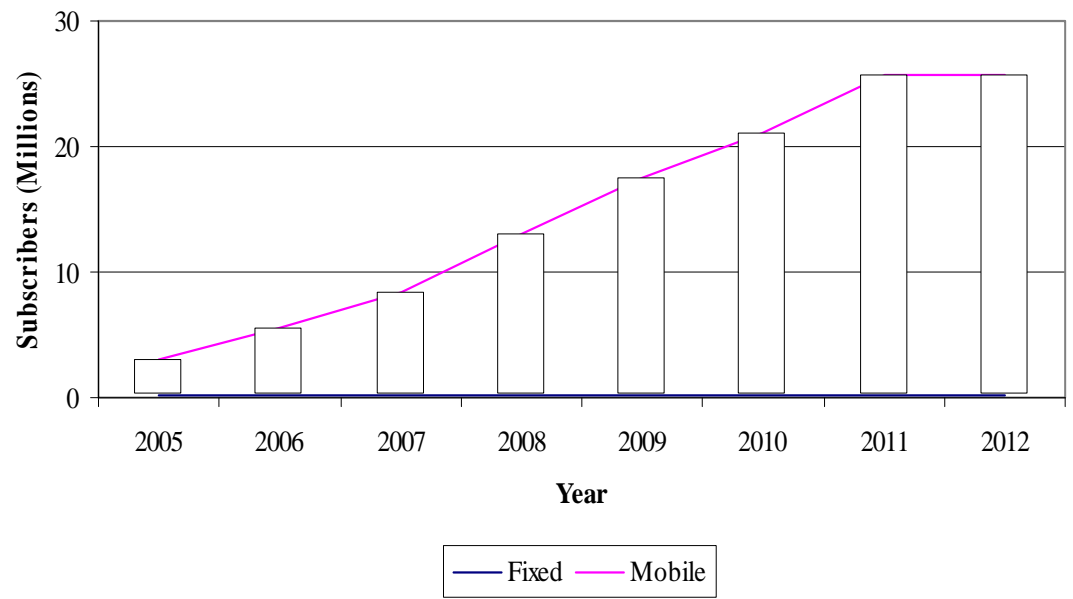

Figure 10. Total cost of ownership of a mobile phone in Tanzania (Source: MDI (2013)). 


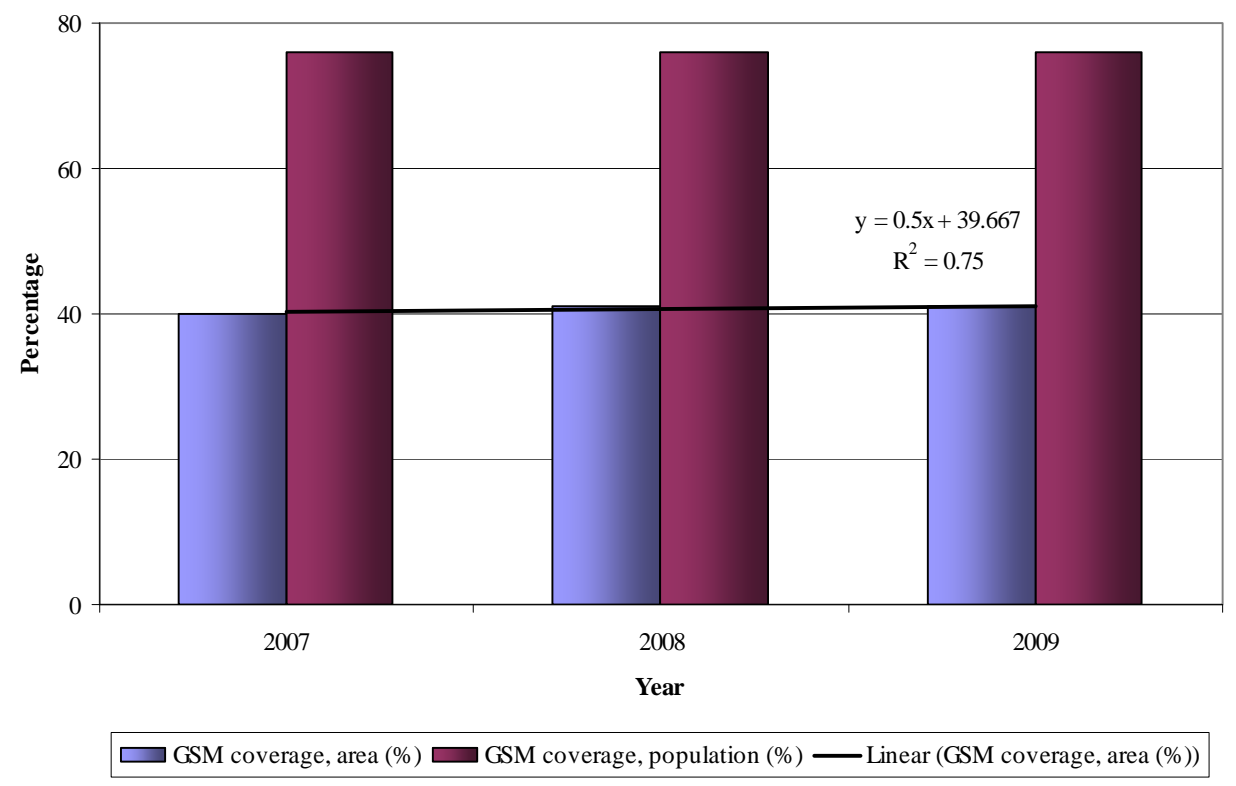

Figure 11. GSM technology coverage (Source: MDI (2013)).

ensure that the changes in TCO is reflected in the consumers' end and becomes potential for the industry's contribution to develop other sectors specially those sensitive to governance challenges like the water sector.

The industry's data also shed some light on coverage of mobile networks. Results of data analysis shown above indicate that GSM technology coverage by population has remained constant over years. However, coverage by area has had a promising increment over the same period (Figure 11).

The later development is important as it may reflect the size of rural areas being reached by this leading mobile technology.

\section{Conclusions}

In order to overcome traditional and emerging challenges on governance of water resources in LVB, new integrated and innovative tools and techniques are needed. The effectiveness of the tools and techniques depends to a large extent on their accessibility and utilization by stakeholders at each governance scale. Moreover, development and implementation of such tools and techniques should consider various technological and institutional aspects at various governance scales in order to avoid frustrating failure and wastage of invaluable resources. This study has identified main constraints affecting accessibility and utilization of mobile phones for addressing water resources governance in LVB to include income poverty and low education prevailing among stakeholders. The study serves as part of situation analysis for further research work. It partly builds the foundation upon which other activities of the research depend. Although, there are a number of constraints in accessing and utilizing mobile phones, many opportunities are availed by the industry for more inclusive technology. The ever increasing penetration rate and coverage of mobile networks combined with the wide range of solutions and platforms have potential to make mobile phones a choice technology in addressing water resources governance challenges in Tanzania. However, the role of public policy to top up as the inclusive strategies is paramount. One of them is through empowering lower scales with mobile phone access and playing a more supportive role in the regulations of mobile phone service provision.

\section{ACKNOWLEDGEMENTS}

Research team acknowledges Lake Victoria Research Initiative (VicRes), Inter-University Council for East Africa (IUCEA) and Swedish International Development Agency (SIDA) for supporting the research of which this paper is one of the outputs. The team also acknowledges the kind and material support received from stakeholders at different levels in the Lake Victoria Basin during the entire period of the research. The team wishes to thank the management and staff of Busitema University, Kigali Institute of Science and Technology and the University of Dodoma for their administrative support.

\section{REFERENCES}

Ally M (2007). Mobile Learning. Int. Rev. Res. Open Distance Learn. 8 (2):1492-3831.

Devore JL, Peck R (1993). Statistics: The exploration and analyisis of data 2nd edition Duxbury Press (Belmont,Califonia) 
Duncombe R, Boateng R (2009). Mobile Phones and Financial Services in Developing Countries: A Review of Concepts, Methods, Issues, Evidence and Future Research Directions. Third World Q 30(7):1237-1258.

East African Community (EAC) (2010). EAC Facts and Figures - 2009, Arusha: EAC Secretariat.

Frantz D (nd). Global Warming as a Water Resource Challenge in Southern Asia, http://www.globalministries.org/get-involved/justiceand-advocacy/water/global-warming-as-a-water-resour.html, [Accessed on 12 March 2014]

Fudík, K., Sabol T, Dulinová V (nd). Policy Modelling Supported by eParticipation ICT Tools, OCOPOMO Project, http://web.tuke.sk/feicit/furdik/publik/metteg10 OCOPOMO paper.pdf

Hultman T (2013). Nigeria: Cell Phones for Farmers to Cut Corruption, Deliver Services, All Africa, http://allafrica.com/stories/printable/201301150001.html, [Accessed on 10 March 2014]

InfoDev (2013). The Mobile Innovation Roadshow: the 'next frontier' for economic growth in Southern Africa. http://www.infodev.org/en/Article.985.html [Accessed on 10th March 2014]

Islam MM, Masum AKM (2010). Mobile Commerce and Mobile Payment: A Study on Islamic Perspective, IIUC Studies Vol. 7.

ITU (2011). The Role of ICT in Advancing Growth in Developing Countries, International Telecommunication Union, http://www.itu.int/ITU-

D/ldc/turkey/docs/The_Role_of_ICT_in_Advancing_Growth_in_LDCs _Trends_Challenges_and_Opportunities.pdf [Accessed on 10 March 2014]

Jones M, Marsden G (2006). Mobile Interaction Design, West Sussex, John Wiley and Sons.

Loudon M (2009). Mobile Phones for Data Collection, MobileActive.com,http://www.mobileactive.org/howtos/mobilephones-data-collection [Accessed on 10 March 2014]

Mbilinyi DAS, Masanja A, Sakara A, Mahundi B (2007). Guidelines for Establishing Community Based Collaborative Fisheries Management In Marine Waters Of Tanzania, Ministry of Livestock and Fisheries Development, Fisheries Development Division \& WWF Tanzania Programme Office,

MDI (2013). Mobile Industry Market Statistics, Mobile Development Intelligence

http://www.mobiledevelopmentintelligence.com/statistics\#,

(MDI),

[Accessed on 10th March 2014]

Medalye J, Hubbart JA (2008). Water resources. In: Encyclopedia of Earth. Eds. Cutler J.

Moum A (2006). A Framework for Exploring the ICT Impact on the Architectural Design Process, ITcon Vol. 11 (2006), Moum, pg. 410, http://www.itcon.org/data/works/att/2006_30.content.07890.pdf

Okurut, T. (2010) Key Note Address: Integrated Environmenta Protection Approaches: Strengthening the role of Water Supply Operators in Resource Conservation, 15th International African Water Congress and Exhibition Commonwealth Resort, Munyonyo, Kampala, Uganda, 16th March 2010

Ospina AV, Heeks R (2010). Unveiling the Links between ICTs \& Climate Change in Developing Countries: A Scoping Study, IDRC/CRDI

Rogers P, Hall A (2003). Effective Water Governance, Global Water Partnership Technical Committee (TEC), Background paper No. 7, Global Water Partnership, http://www.gwp.org/Global/ToolBox/Publications/Background\%20pap ers/07\%20Effective\%20Water\%20Governance $\% 20 \% 282003 \% 29 \% 2$ OEnglish.pdf [Accessed on 15 January 2015]

Schuchardt L, Steinmetz H, Ehret J, Ebert A, Schmitt TG (2004). Scalable mobile information system to support the treatment. Water Sci. Technol. 50:11(199-206).

Sehlke G (2008). Water Resources Challenges in the Next Decade and Beyond: Global Change, American Water Resources Association, http://awramedia.org/mainblog/2008/04/23/water-resourceschallenges-in-the-next-decade-and-beyond-global-change/, [Accessed on 08 March 2014]
Selwhn N (2002). Telling tales on technology. Quantitative studies of Technology and education. Burlington, VT: Ashgate

TCRA (2013). Quarterly Telecommunications Statistics, Tanzania Communications Regulatory Authority, http://www.tcra.go.tz/publications/telecom.html, [Accessed on 10th March 2014]

Tebbutt THY (1998). Principles of Water Quality Control, $5^{\text {th }}$ Edition, Elsevier Ltd.

UN News Centre (2013). Deputy UN chief calls for urgent action to tackle global sanitation crisis: http://www.un.org/apps/news/story.asp?NewsID $=44452 \& \mathrm{Cr}=$ sanitatio n\&Cr1=\#.UU7Y2oaCmji [Accessed on 10 March 2014]

UNEP (2010). Africa Water Atlas. Division of Early Warning and Assessment (DEWA). United Nations Environment Programme (UNEP). Nairobi, Kenya, https://na.unep.net/atlas/africaWater/downloads/chapters/africa_wate r_atlas_123-174.pdf [Accessed on 10 March 2014]

Unhelkar B (2009). Handbook of Research in Mobile Business: Technical, Methodological, and Social Perspectives, New York: Information Science Reference

Vodafone/Accenture (2011). Mobile Phone Technologies for Improving Agricultural Income and Productivity http://www.vodafone.com/content/dam/vodafone/about/sustainability/ 2011/pdf/connected_agriculture.pdf [Accessed on 10 March 2014]

Weggoro NC, Ntamubano W (2010). EAC governance structure with regard to watershade management. Paper presented at the "Symposium on science and policy linkages for trans boundary water management" http://www.eac.int/environment/index.php [Accessed: 25 July 2014]

Weston TR (2008). Development of the Marcellus Shale-Water Resource Challenge, Kirkpatrick \& Lockhart Preston Gates Ellis LLP, http://www.wvsoro.org/resources/marcellus/Weston.pdf, [Accessed on 12 March 2014]

Wong S (2009). Lesson from a Participatory Trans-boundary water governance project in West Africa, In: IIED (2009) Participatory Learning and Action: community-based Adaptation to climate change, IIED, London

World Bank (2013). Philippines: Geo-tagging for Efficient, Cost-Effective Project Management http://www.worldbank.org/en/news/feature/2013/02/19/geo-taggingfor-efficient-cost-effective-projectmanagement?cid=EXT_FBWB_D_EXT, [Accessed on 10 March 2014]

WRG2030 (2009). Charting Our Water Future: Economic frameworks to inform decision-making, Water Resource Group 2030, The Barilla Group, The Coca-Cola Company, The International Finance Corporation, McKinsey \& Company, Nestlé S.A., New Holland Agriculture, SABMiller Plc, Standard Chartered Bank, and Syngenta AG.,

http://www.mckinsey.com/client_service/sustainability/latest_thinking/ charting_our_water_future [Accessed on 13 March 2014]. 